\title{
MENINGKATKAN HASIL BELAJAR SISWA DENGAN MEDIA BUTA (GABUS PITA)
}

\author{
Intan Mustika Yulias Tobing, Chusnal Ainy, Endang Suprapti \\ Universitas Muhammadiyah Surabaya \\ intanmyt19@gmail.com, chusnal.pendmat@fkip.um-surabaya.ac.id, \\ endang.pendmat@fkip.um-surabaya.ac.id
}

\begin{abstract}
ABSTRAK
Kriteria ketuntasan minimum (KKM) SMP Muhammadiyah 5 Surabaya kelas VII adalah 80 dan siswa yang tuntas belajar sebanyak $\geq 80 \%$. Permasalahan yang terjadi di kelas VII-I SMP Muhammadiyah 5 Surabaya adalah nilai rata-rata siswa $\leq$ KKM. Ini terlihat dari 20 siswa, hanya 2 siswa yang tuntas atau $10 \%$, sementara 18 siswa tidak tuntas belajar atau sebesar $90 \%$, skor ratarata adalah 55,55 .

Penelitian ini menggunakan pembelajaran menggunakan media BUTA (Cork Ribbon). Sampel penelitian ini adalah siswa kelas VII-I SMP Muhammadiyah 5 Surabaya. Penelitian ini adalah penelitian tindakan kelas (PTK) dengan pelaksanaan 2 siklus.

Dari hasil penelitian pada siklus I dapat disimpulkan bahwa hasil belajar siswa kelas VII-I mengalami peningkatan. Hal ini dapat dilihat dari kelengkapan siswa sebelum tindakan $10 \%$ atau 2 siswa meningkat menjadi 55\% atau sebanyak 11 siswa yang tuntas. Sedangkan siklus kedua $85 \%$ atau 17 siswa tuntas dengan rata-rata 87,55.
\end{abstract}

Katakunci: Media BUTA, Hasil pembelajaran

\section{ABSTRACT}

The minimum completeness criteria (KKM) of SMP Muhammadiyah 5 Surabaya class VII is 80 and students who complete the learning as many as $\geq 80 \%$. The problems that occur in class VII-I SMP Muhammadiyah 5 Surabaya is the average value of students $\leq K K M$. This was seen from 20 students, only 2 students completed or $10 \%$, while 18 students were not complete learn or by $90 \%$, the average score was 55.55 .

This research used learning using BUTA (Cork Ribbon) media. The sample of this research were students of class VII-I SMP Muhammadiyah 5 Surabaya. This research was a class action research (PTK) with the implementation of 2 cycles.

From the results of research on the cycle I can be concluded that the results of student learning class VII-I has increased. This can be seen from the completeness of the students before the action of $10 \%$ or 2 students increased to $55 \%$ or as many as 11 students who completed. While the second cycle $85 \%$ or 17 students complete with an average of 87.55 .

Keywords: BUTA media, Learning Outcomes.

\section{PENDAHULUAN}

Matematika merupakan ilmu yang hampir ada pada setiap jenjang Pendidikan mulai dari bangku sekolah dasar sampai tingkat perguruan tinggi. Matematika juga sebagai salah satu cabang ilmu pengetahuan yang berperan penting dalam kehidupan setiap manusia. Menyadari pentingnya hal tersebut, belajar matematika seharunya menjadi kebutuhan dan kegiatan yang menyenangkan. Namun dewasa ini, mata pelajaran yang masih dianggap paling sulit dan susah dipahami kebanyakan siswa adalah 
matematika. Berdasarkan hasil survei disekolah, masih banyak siswa yang hasil belajar matematikanya tergolong rendah. Hal tersebut dikarenakan masih banyak guru yang menggunakan metode ceramah dalam pembelajaran matematika sehingga mengakibatkan siswa cenderung kurang aktif karena pembelajaran yang kurang menarik dan menyenangkan. Salah satu cara untuk mengatasi permasalahan tersebut perlu adanya solusi untuk meningkatkan hasil belajar matematika siswa. Salah satunya dengan menggunakan media yang sesuai dengan mata pelajaran yang di ampuh. Belajar matematika dengan cara yang menarik dan menyenangkan merupakan tugas guru.

Guru merupakan sosok yang keberadaannya tidak dapat digantikan oleh media atau fasilitas pembelajaran apapun. Kehadiran guru masih tetap diperlukan, guru harus tetap melaksanakan pembelajaran secara langsung di depan siswa. Oleh karena itu apapun alasannya guru harus mengajar langsung di depan siswa agar tujuan pembelajaran yang ditetapkan dapat tercapai. Seiring dengan perkembangan jaman yang berdampak terhadap perubahan kurikulum pembelajaran, kualitas pembelajaran perlu selalu ditingkatkan. Keadaan tersebut dapat dimulai dengan peningkatan kompetensi para guru, baik dalam menyampaikan materi, menggunakan metode dan teknik mengajar yang tepat, menggunakan media pembelajaran dalam rangka memenuhi kebutuhan peserta didik.

Guru yang profesional pada hakekatnya adalah mampu menyampaikan materi pembelajaran secara tepat sesuai dengan kebutuhan belajar peserta didik. Namun demikian untuk mencapai ke arah tersebut perlu berbagai latihan, penguasaan dan wawasan dalam pembelajaran, termasuk salah satunya menggunakan model dan metode pembelajaran yang tepat. Dalam pembelajaran matematika, guru tidak cukup terfokus hanya pada satu model dan metode tertentu saja. Guru perlu mencoba menerapkan berbagai model dan metode yang sesuai dengan tuntutan materi pembelajaran, termasuk dalam penerapan model pembelajaran kooperatif dengan metode belajar kelompok. Pemilihan model dan metode yang tepat tersebut akan dapat meningkatkan pencapaian hasil belajar sesuai dengan yang diharapkan.

Miftahul huda (2012:68) dalam Harjoko (2014:1) menyatakan "jika model pembelajaran kooperatif tidak dirancang dengan baik maka pembelajaran kooperatif akan berdampak pada munculnya beberapa siswa yang tidak bertanggungjawab secara personal pada tugas kelompoknya, selain itu beberapa siswa dianggap tidak 
mampu cenderung diabaikan oleh anggota kelompok lainya". Untuk menghindari dampak tersebut penggunaan model pembelajaran kooperatif TGT (Teams Games Tournament) yang berisigame akademik mampu mendorong semua anggota kelompok untuk terlibat dalam pengerjaan tugas kelompoknya. "Dalam TGT setiap siswa ditempatkan dalam satu kelompok yang terdiri dari 3 orang yang berkemampuan rendah, sedang dan tinggi" (Miftahul Huda, 2012:116). Melalui model tersebut siswa yang berkemampuan rendah dapat berperan aktif dalam pembelajaran melalui kelompoknya.

Berdasarkan konsep tersebut menunjukkan bahwa model pembelajaran kooperatif perlu diterapkan dan dikembangkan guru dengan terlebih dahulu menguasai strategi atau langkah-langkahnya. Model pembelajaran kooperatif merupakan variasi guru dalam melaksanakan pembelajaran perlu dikembangkan. Guru perlu secara cermat memilih materi yang tepat untuk menggunakan model pembelajaran ini tidak hanya itu guru juga harus bisa menyesuaikan media dengan materi pembelajaran yang diampuh, sehingga hasil belajar siswa lebih optimal. Keberadaan penerapan metode belajar kelompok untuk mata pelajaran matematika sangat diperlukan. Para siswa dapat saling sharing pengetahuan dalam pengambilan keputusan untuk memecahkan masalah yang dihadapi bersama. Keadaan tersebut memberikan manfaat sebagai pengalaman belajar yang nyata bagi para siswa apalagi mata pelajaran matematika secara keseluruhan lebih menekankan kepada praktik dibandingkan dengan hanya memahami konsep secara abstrak saja. Berdasarkan hal-hal yang telah dikemukakan selanjutnya menarik untuk dikaji lebih lanjut dalam bentuk penelitian, sehingga judul yang ditetapkan: "Meningkatkan Hasil Belajar Matematika Siswa SMP Kelas VII Melalui Model Pembelajaran Kooperatif TGT (Teams Games Tournament) Pada Materi Penyajian Data Dengan Media BUTA (Gabus Pita).

Adapun tujuan penelitian ini sebagai berikut :

1. Mendeskripsikan peningkatan hasil belajar siswa dengan menggunakan media BUTA (gabus pita) dalam materi penyajian data pada kelas VII SMP Muhammadiyah 5 Surabaya.

2. Mendeskripsikan respon siswa mengenai penggunaan media BUTA (gabus pita) pada materi penyajian data pada kelas VII SMP Muhammadiyah 5 Surabaya.

\section{METODE PENELITIAN}

Penelitian ini adalah Penelitian Tindakan Kelas (PTK). Rancangan penelitian tindakan kelas dipilih karena masalah yang akan di pecahkan berasal dari praktik 
pembelajaran di kelas sebagai upaya untuk memperbaiki pembelajaran dan meningkatkan kemampuan siswa. Hal ini sesuai dengan karakteristik penelitian tindakan kelas. Instrument yang digunakan berupa Data hasil tes belajar dan data keaktifan belajar siswa.

Cara yang ditempuh untuk menganalisis hasil kerja siswa adalah dengan melihat dan menbandingkan skor hasil tes soal penyajian data kemudian dihitung presentase siswa yang sudah tuntas pada masingmasing siklus. Apabila besar presentase ketuntasan siswa mengikuti hasil tes tersebut mengalami peningkatan sebesar $80 \%$, dapatlah diartikan bahwa hasil belajar terhadap materi penyajian data telah meningkat sesuai dengan indikator keberhasilan, sehingga tidak perlu ada siklus berikutnya. Tetapi sebaliknya, jika hasil belajar siswa tidak meningkat atau rendah, maka perlu adanya siklus lagi untuk mendapatkan hasil yang sesuai dengan indikator keberhasilan.

Adapun rumus perhitungan menurut Arikunto (2008:236), sebagai berikut:

1. Analisis data untuk prestasi belajar digunakan tingkat penguasaan

$$
T p=\frac{S_{i}}{S_{\max }} \times 100 \%
$$

Keterangan :

$T p=$ tingkat penguasaan siswa

$$
\begin{aligned}
S_{i}= & \text { skor (nilai) yang didapat } \\
& \text { siswa } \\
S_{\text {max }}= & \text { skor (nilai) maksimal }
\end{aligned}
$$

2. Untuk mencari rata-rata dan simpangan baku

$$
\begin{gathered}
\bar{x}=\frac{\sum x_{i}}{n} \\
S^{2}=\frac{n \sum x_{i}^{2}-\sum\left(x_{i}\right)^{2}}{n(n-1)}
\end{gathered}
$$

Keterangan:

$\bar{x}=$ nilai rata- rata

$x_{i}=$ data nilai siswa ke- $\mathrm{i}$

$n$ = banyak data

$S$ = simpangan baku

3. Analisis data untuk aktifitas siswa dengan teknik persentase

$$
A K=\frac{n\left(A_{i}\right)}{n\left(A_{\text {Tot }}\right)} \times 100 \%
$$

Keterangan :

$$
\begin{aligned}
A K= & \text { persentase aktifitas } \\
& \text { siswa } \\
n\left(A_{i}\right)= & \text { jumlah aktifitas ke-i } \\
& \text { yang muncul } \\
n\left(A_{\text {Tot }}\right)= & \text { jumlah aktifitas } \\
& \text { keseluruhan }
\end{aligned}
$$

4. Analisis data untuk mengetahui nilai peningkatan prestasi belajar siswa

Peningkatan prestasi $=\frac{x_{2}-x_{1}}{x_{1}} \times 100 \%$

Keterangan:

$x_{1}=$ nilai rata-rata pertama

$x_{2}=$ nilai rata-rata kedua 
5. Analisis data untuk angket respon siswa

secara deskriptif yang dinyatakan dengan prosentase untuk tiap aspek yang dihitung menggunakan rumus :

Persentase respon tiap aspek $=\frac{A}{B} \times 100 \%$

Riduwan (2007:15)

Keterangan:

$A=$ jumlah siswa yang memberi respon

$B=$ jumlah siswa seluruhnya

Tabel 1. Persentase Kriteria Penilaian

Angket Respon Siswa

\begin{tabular}{|c|c|c|}
\hline No & Persentase & Kategori \\
\hline 1 & $0 \%-20 \%$ & Sangat buruk \\
\hline 2 & $21 \%-40 \%$ & Buruk \\
\hline 3 & $41 \%-60 \%$ & Cukup \\
\hline 4 & $61 \%-80 \%$ & Baik \\
\hline 5 & $81 \%-100 \%$ & Sangat Baik \\
\hline \multicolumn{2}{|c|}{ Riduwan (2007:15) } \\
\hline
\end{tabular}

\section{HASIL PENELITIAN}

Pada BAB III telah dijelaskan bahwa penelitian ini adalah penelitian tindakan kelas (PTK). Terdapat dua data yang mendukung diadakannya penelitian tindakan kelas (PTK), yaitu data sebelum tindakan penelitian dan data sesudah tindakan penelitian. Data sebelum tindakan penelitian diperoleh dari hasil ulangan tengah semester (UTS) yang didapat dari guru mata pelajaran matematika kelas VII. Data sesudah tindakan penelitian adalah data yang diambil ketika penelitian berlangsung, yakni hasil tes yang diberikan serta hasil observasi pada tiap siklus. Berikut deskripsi hasil data yang diperoleh:

Tabel 2. Hasil Belajar Siswa Sebelum dan Sesudah Tindakan

\begin{tabular}{|c|c|c|c|}
\hline & Data awal & Siklus I & Siklus II \\
\hline Rata-rata & 55,55 & 78,275 & 87,55 \\
\hline
\end{tabular}

Tabel 3. Nilai Rata-rata Aktivitas Siswa

\begin{tabular}{|c|c|c|c|c|c|c|c|c|}
\hline Hasil & Jumlah & \multicolumn{7}{|c|}{ Rata-rata aktivitas } \\
\cline { 3 - 9 } observasi & siswa & $\mathbf{1}$ & $\mathbf{2}$ & $\mathbf{3}$ & $\mathbf{4}$ & $\mathbf{5}$ & $\mathbf{6}$ & $\mathbf{7}$ \\
\hline Siklus I & 20 & 15,25 & 10,25 & 25,75 & 7,75 & 1,5 & 7,5 & 4 \\
\hline Siklus II & 20 & 16,25 & 14,25 & 27 & 4,75 & 2,5 & 5,75 & 1,5 \\
\hline
\end{tabular}

Tabel 4. Nilai Presentase Aktivitas Siswa

\begin{tabular}{|c|c|c|c|c|c|c|c|c|}
\hline Hasil & Jumlah & \multicolumn{7}{|c|}{ Presentase aktivitas siswa (\%) } \\
\cline { 3 - 9 } observasi & siswa & $\mathbf{1}$ & $\mathbf{2}$ & $\mathbf{3}$ & $\mathbf{4}$ & $\mathbf{5}$ & $\mathbf{6}$ & $\mathbf{7}$ \\
\hline Siklus I & 20 & 21,18 & 14,23 & 35,76 & 10,76 & 2,08 & 10,41 & 5,55 \\
\hline Siklus II & 20 & 22,56 & 19,79 & 37,5 & 6,59 & 3,47 & 7,98 & 2,08 \\
\hline
\end{tabular}

Tabel 5. Rata-rata dan Presentase Angket Respon Siswa

\begin{tabular}{|c|c|c|c|c|c|c|c|}
\hline Jumlah & Total & \multicolumn{2}{|c|}{ Jumlah respon } & \multicolumn{2}{c|}{ Rata-rata respon } & \multicolumn{2}{c|}{ Persentase respon } \\
\cline { 3 - 8 } siswa & respon & Ya & Tidak & Ya & Tidak & Ya & Tidak \\
\hline 20 & 160 & 155 & 5 & 19 & 1 & $97 \%$ & $3 \%$ \\
\hline
\end{tabular}


PEMBAHASAN

Dalam pembahasan ini akan dijelaskan hasil analisis data penelitian dari siklus I dan siklus II secara terperinci, sebagai berikut :

\section{Siklus I}

\section{a. Perencanaan}

Perencanaan pembelajaran pada siklus I dimulai dengan observasi pada kondisi kelas VII smp muhammadiyah 5 surabaya yang akan dijadikan subjek penelitian, terdapat 9 kelas yaitu kelas VII-A, VII-B, VII-C, VII-D, VIIE, VII-F, VII-G, VII-H, VII-I. Subyek yang digunakan dalam penelitian ini yaitu kelas VII-I. Pengambilan subjek ini ditentukan sendiri oleh guru metematika kelas VII. Setelah subjek penelitian ini ditentukan, maka peneliti merancang Rencana Pelaksanaan Pembelajaran Siklus I (RPP 1) yang akan dilaksanakan selama 2 pertemuan. Untuk mengetahui aktivitas siswa selama pembelajaran siklus I berlangsung, serta peneliti merancang lembar observasi aktivitas siswa.

\section{b. Pelaksanaan}

Pelaksanaan pembelajaran pada siklus I dilaksanakan pada tanggal 09 Mei dan tanggal 10 Mei 2017. Dimana pertemuan pertama dilaksanakan pada hari selasa, 09 Mei 2017 dan pertemuan kedua dilaksanakan pada hari Rabu, 10 Mei 2017.
Pada pertemuan pertama guru menyajikan materi sesuai dengan RPP siklus I yang sudah dibuat. Pembelajaran dimulai dengan kegiatan pendahuluan yaitu menyampaikan tujuan pembelajaran dan kegiatan apersepsi. Kemudian siswa dikondisikan dalam beberapa kelompok diskusi dengan masingmasing kelompok terdiri dari 5 siswa. Masing-masing kelompok menerima soal kelompok siklus I. Siswa saling berdiskusi dengan anggota kelompoknya masingmasing untuk merancang menyelesaikan soal kelompok yang didapat. Dengan percaya diri siswa mengerjakan soal dan berdiskusi dengan anggota kelompoknya masing-masing. Kelompok yang sudah selesai dan siap, mempresentasikan hasil diskusinya di depan kelas. Sedangkan siswa yang lain diberikan kesempatan untuk bertanya kepada kelompok yang presentasi. Setelah selesai presentasi kegiatan pembelajaran dilanjutkan dengan mengerjakan soal individu. Dan pembelajaran pada pertemuan pertama ditutup dengan refleksi dan disertai tanya jawab mengenai kesimpulan dari materi yang telah dipelajari serta kesan pembelajaran yang telah dilakukan dan diberitahu tentang materi yang akan dibahas pada pertemuan selanjutnya. 


\section{c. Observasi}

\section{1) Observasi Aktivitas Guru}

Pada proses observasi guru, terdapat 1 observer yang mengobservasi dan mencatat aktivitas guru selama proses pembelajaran, mulai membuka hingga menutup pembelajaran. Hal ini dapat dilihat pada lembar observasi aktifitas guru. Aktivitas yang dilakukan guru sudah cukup baik, diantaranya guru membuka pembelajaran dengan apersepsi, guru memberikan kesempatan kepada siswa untuk bertanya apabila siswa mengalami kesulitan, guru menjelaskan materi pembelajaran, guru memberikan tugas kelompok/individu, kemudian diakhir pembelajaran, guru membuat kesimpulan bersama dengan siswa terkait materi yang sedang dipelajari hari itu, menyampaikan tentang pembelajaran pada pertemuan selanjutnya serta menutup pembelajaran dengan berdoa bersamasama.

\section{2) Observasi Aktivitas Siswa}

Untuk melakukan observasi aktivitas siswa pada proses pembelajaran diperlukan 2 observer, yaitu observer pertama mengobservasi kelompok 1 dan 2, observer kedua mengobservasi kelompok 3 dan 4. Observasi aktivitas siswa ini dilakukan pada tiap siswa. Tujuan dari pengelompokan siswa adalah untuk mempermudah dalam melakukan observasi, serta siswa bisa bekerja sama dengan siswa lain. Peneliti melakukan observasi aktivitas siswa yang terancang dalam lembar observasi.

Berdasarkan hasil pengamatan pada lembar observasi, dapat dilihat bahwa observasi aktivitas siswa dilakukan setiap 5 menit sekali. Pada pertemuan pertama, aktivitas siswa sudah cukup baik. Hal ini nampak terlihat keaktifan siswa pada proses pembelajaran. Dimana siswa mampu menjawab pertanyaan guru tentang tujuan pembelajaran yang akan dilaksanakan dan bertanya pada guru apabila mengalami kesulitan.

Pada pertemuan pertama, dengan mandiri siswa mengkondisikan dalam beberapa kelompok diskusi, dengan masing-masing kelompok terdiri dari 5 siswa. Kemudian terbentuk 4 kelompok diskusi dalam kelas tersebut. Pada pelaksanaan siklus I ini siswa terlihat aktif dalam diskusi untuk mengerjakan soal kelompok yang sudah diberikan dengan bimbingan guru, dengan 
kreatif dan inovatif siswa mampu menyelesaikan masalah tersebut dengan baik. Apabila selesai mengerjakan soal kelompok, masing-masing kelompok diberi kesempatan untuk mempresentasikan hasil diskusinya. Ketika perwakilan salah satu kelompok telah selesai mempresentasikan tentang materi yang dipelajari pada hari itu, kemudian kelompok lain diberi kesempatan bertanya apabila mengalami kesulitan tentang materi yang telah disampaikan oleh kelompok penyaji. Hal ini dilakukan agar siswa lebih terlibat dalam proses pembelajaran dan lebih memahami materi yang telah dipelajari. Untuk menumbuhkan kekritisan dan keterlibatan siswa, guru tidak langsung menjawab pertanyaan-pertanyaan yang diajukan siswa, guru memberi kesempatan kepada siswa lain untuk menjawab pertanyaan yang telah diajukan temannya. Namun, apabila siswa lain kesulitan dalam menjawab pertanyaan maka guru menjawab pertanyaan tersebut. Selama proses pembelajaran siswa selalu tekun dan selalu ingin mencapai prestasi yang lebih baik.

Kategori memperhatikan/ mendengarkan penjelasan guru memiliki rata-rata sebesar 15,25 , kategori membaca buku paket memiliki rata-rata 10,25 , kategori mengerjakan soal (individu maupun kelompok) memiliki ratarata 25,75, kategori berdiskusi antar siswa memiliki rata-rata 7,75, kategori mempresentasikan hasil kelompok memiliki rata-rata 1,5, kategori memperhatikan kelompok lain presentasi memiliki rata-rata 7,5 , kategori perilaku yang tidak relevan memiliki ratarata 4.

Dari uraian di atas kategori rata-rata tertinggi mengerjakan soal (individu maupun kelompok) memiliki rata-rata 25,75 .

\section{d. Refleksi}

Berdasarkan hasil tes pada siklus I, nilai rata-rata siswa yang dicapai adalah 78,275artinya belum mencapai KKM yang ditentukan yaitu $\geq 80$. Siswa yang tuntas belajarnya sebesar 55\% sedangkan sebesar 45\% tidak tuntas belajar. Karena banyaknya siswa yang tuntas belajar pada siklus I belum mencapai80\%, sehingga diperlukan adanya suatu tindakan pada siklus II agar hasil belajar siswa dapat mencapai indikator keberhasilan.

\section{Siklus II}

\section{a. Perencanaan}

Berdasarkan hasil refleksi pada siklus I yang belum mencapai indikator keberhasilan penelitian maka peneliti melakukan perencanaan pada siklus II agar pembelajaran lebih 
efektif sehingga indikator keberhasilan tercapai. Pada tahap perencanaan siklus II,RPP yang sudah disiapkan didiskusikan kembali dengan guru yang bersangkutan agar persiapan lebih matang dan tindakan bisa dilaksanakan dengan lebih baik.

\section{b. Pelaksanaan}

Pelaksanaan tindakan kelas pada siklus II dilaksanakan pada tanggal 16 Mei 2017. Dimana pertemuan ketiga dilaksanakan pada hari selasa, 16 Mei 2017. Pada pertemuan ketiga guru menyajikan materi sesuai dengan RPP 3 (siklus II) yang sudah dibuat. Pembelajaran dimulai dengan kegiatan pendahuluan yaitu menyampaikan tujuan pembelajaran dan kegiatan apersepsi. Kemudian siswa dikondisikan dalam 4 kelompok dengan masing-masing kelompok terdiri atas 5 orang. Saat diskusi masing-masing kelompok diberi soal kelompok siklus II tentang diagram garis. Siswa saling berdiskusi dengan anggota kelompoknya masing-masing untuk mengerjakan soal kelompok siklus II. Kemudian kegiatan pembelajaran dilanjutkan dengan presentasi, bagi kelompok yang sudah selesai dan siap, mempresentasikan hasil diskusinya di depan kelas, sedangkan siswa lain diberi kesempatan tanya jawab kepada kelompok yang berpresentasi di depan kelas. Setelah presentasi selesai, kegiatan pempelajaran dilanjutkan dengan mengerjakan soal individu siklus II dan guru memberikan penghargaan bagi kelompok terbaik. Kegiatan pembelajaran pada pertemuan ketiga ditutup dengan refleksi dan disertai tanya jawab mengenai kesimpulan dari materi yang telah dipelajari serta kesan pembelajaran yang telah dilakukan.

Pada pelaksanaan pembelajaran ini, dilakukan observasi terhadap aktivitas siswa selama pembelajaran berlangsung.

\section{c. Observasi}

\section{1) Observasi aktivitas guru}

Pada proses observasi guru, terdapat 1 observer yang mengobservasi dan mencatat aktivitas guru pada saat proses pembelajaran berlangsung. Hal ini dapat dilihat pada lembar observasi aktifitas guru. Aktivitas yang dilakukan guru sudah cukup baik, diantaranya guru membuka pembelajaran dengan apersepsi, guru memberikan kesempatan kepada siswa untuk bertanya apabila siswa mengalami kesulitan, guru menjelaskan materi pembelajaran, guru memberikan tugas 
kelompok/individu, kemudian diakhir pembelajaran, guru membuat kesimpulan bersama dengan siswa terkait materi yang sedang dipelajari hari itu, menyampaikan tentang pembelajaran pada pertemuan selanjutnya serta menutup pembelajaran dengan berdoa bersamasama.

\section{2) Observasi aktivitas siswa}

Aktivitas siswa pada siklus II ini hampir sama dengan siklus I, aktivitas siswa sudah cukup baik. Hal ini nampak terlihat pada keaktifan siswa pada proses pembelajaran. Untuk melakukan observasi aktivitas siswa pada proses pembelajaran diperlukan 2 observer, yaitu observer pertama mengobservasi kelompok 1 dan 2, observer kedua mengobservasi kelompok 3 dan 4. Observasi aktivitas siswa ini dilakukan pada tiap siswa. Tujuan dari pengelompokan siswa adalah untuk mempermudah dalam melakukan observasi, serta siswa bisa bekerja sama dengan siswa lain. Peneliti melakukan observasi aktivitas siswa yang terancang dalam lembar observasi.

Berdasarkan hasil lembar observasi, dapat dilihat bahwa observasi aktivitas siswa dilakukan setiap 5 menit sekali. Pada pertemuan pertama, aktivitas siswa sudah cukup baik. Hal ini nampak terlihat keaktifan siswa pada proses pembelajaran. Dimana siswa mampu menjawab pertanyaan guru tentang tujuan pembelajaran yang akan dilaksanakan dan bertanya pada guru apabila mengalami kesulitan.

Pada pertemuan ketiga,
siswa dikondisikan dalam
beberapa kelompok diskusi,
dengan masing-masing kelompok terdiri dari 5 siswa. Kemudian terbentuk 4 kelompok diskusi dalam kelas tersebut. Pada pelaksanaan siklus I ini siswa terlihat aktif dalam diskusi untuk mengerjakan soal kelompok yang sudah diberikan dengan bimbingan guru, dengan kreatif dan inovatif siswa mampu menyelesaikan persamaan tersebut dengan baik. Apabila selesai mengerjakan soal kelompok, masing-masing kelompok diberi kesempatan untuk mempresentasikan hasil diskusinya. Ketika perwakilan salah satu kelompok telah selesai mempresentasikan tentang materi yang dipelajari pada hari itu, kemudian kelompok lain diberi kesempatan bertanya apabila mengalami kesulitan tentang materi yang telah disampaikan oleh kelompok penyaji. Hal ini dilakukan agar 
siswa lebih terlibat dalam proses pembelajaran dan lebih memahami materi yang telah dipelajari. Untuk menumbuhkan kekritisan dan keterlibatan siswa, guru tidak langsung menjawab pertanyaan-pertanyaan yang diajukan siswa, guru memberi kesempatan kepada siswa lain untuk menjawab pertanyaan yang telah diajukan temannya. Namun, apabila siswa lain kesulitan dalam menjawab pertanyaan maka guru menjawab pertanyaan tersebut. Selama proses pembelajaran siswa selalu tekun dan selalu ingin mencapai prestasi yang lebih baik.

Kategori memperhatikan/ mendengarkan penjelasan guru memiliki rata-rata sebesar 16,25 , kategori membaca buku paket memiliki rata-rata 14,25 , kategori mengerjakan soal (individu maupun kelompok) memiliki ratarata 27 , kategori berdiskusi antar siswa memiliki rata-rata 4,75 , kategori mempresentasikan hasil kelompok memiliki rata-rata 2,5, kategori memperhatikan kelompok lain presentasi memiliki rata-rata 5,75, kategori perilaku yang tidak relevan memiliki ratarata 1,5 .

Dari uraian di atas kategori rata-rata tertinggi mengerjakan soal (individu maupun kelompok) memiliki rata-rata 27.

\section{d. Refleksi}

Berdasarkan hasil tes individu siklus II, nilai rata-rata yang diperoleh siswa kelas VII-I SMP Muhammadiyah 5 Surabaya pada tes individu siklus II adalah 87,55 . sebanyak 17 siswa dari 20 siswa atau $85 \%$ dari seluruh siswa kelas VII-I sudah tuntas belajarnya. Sedangkan 3 siswa dari 20 siswa atau $15 \%$ dari seluruh siswa VII-I belum tuntas belajarnya. Nilai rata-rata ini sudah mencapai indikator keberhasilan dalam satu kelas. Hal ini dikarenakan siswa mencapai standart ketuntasan minimal $80 \%$. Terdapat beberapa faktor yang mempengaruhi peningkatan hasil tes siswa pada siklus II yaitu guru lebih sering memotivasi siswa untuk aktif dalam pembelajaran, siswa lebih aktif dalam diskusidan perilaku tidak relevan jarang dilakukan. Ini berarti indikator keberhasilan penelitian sudah tercapai.

Berdasarkan rekapitulasi hasil angket respon siswa kelas VII-I, hasil angket respon siswa yang terdiri dari 8 pertanyaan yang diberikan kepada 20 siswa kelas VII-I SMP Muhammadiyah 5 Surabaya mendapatkan respon yang baik. Penggunaan media BUTA (gabus pita) untuk materi penyajian data dalam pembelajaran matematika mendapat respon "Ya" sebanyak 155 siswa dengan persentase 


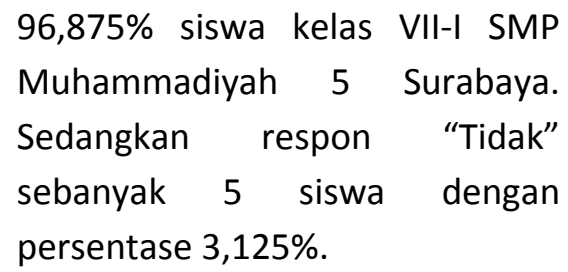

\section{KESIMPULAN}

Dari hasil penelitian pada siklus I dan II dapat disimpulkan bahwa hasil belajar siswa kelas VII-I mengalami peningkatan. $\mathrm{Hal}$ ini dapat dilihat dari kelengkapan siswa sebelum tindakan $10 \%$ atau 2 siswa meningkat menjadi $55 \%$ atau sebanyak 11 siswa yang tuntas. Sedangkan siklus kedua $85 \%$ atau 17 siswa tuntas dengan rata-rata 87,55.

Dengan demikian penggunaan media BUTA (gabus pita) dapat meningkatkan hasil belajar matematika siswa.

\section{DAFTAR PUSTAKA}

Arikunto, Suharsimi. 2008. Penelitian Tindakan Kelas. Jakarta : PT Bumi Aksara.

Harjoko. 2014. Meningkatkan Hasil Belajar Matematika Melalui Penerapan Model Pembelajaran Kooperatif Tipe TGT (Teams Games Tournament) Pada Siswa Kelas $\checkmark$ SDN Kedungjambal 02 Kab. Sukoharjo Tahun Ajaran 20132014. Yogyakarta : Universitas Negeri Yogyakarta.

Riduwan. 2007. Skala Pengukuran Variabel-variabel Penelitian. Bandung : Alfabeta. 